\title{
Sociodemographic factors affecting the quality of life of patients with asthma
}

\author{
This article was published in the following Dove Press journal: \\ Patient Preference and Adherence \\ 18 March 2016 \\ Number of times this article has been viewed
}

\section{Bartosz Uchmanowicz' \\ Bernard Panaszek ${ }^{2}$ \\ Izabella Uchmanowicz' \\ Joanna Rosińczuk ${ }^{3}$ \\ 'Department of Clinical Nursing, ${ }^{2}$ Department and Clinic of Internal Diseases, Geriatry and Allergology, ${ }^{3}$ Department of Nervous System Diseases, Wroclaw Medical University, Wroclaw, Poland}

Background: In recent years, there has been an increased interest in the subjective quality of life (QoL) of patients with bronchial asthma. Patients diagnosed with asthma experience a number of problems with regard to everyday activities and functions, which adversely affects their health-related QoL.

Aim: The aim of this study is to analyze the sociodemographic factors affecting the QoL of patients with asthma.

Patients and methods: The study comprised of 100 patients ( 73 females and 27 males) aged 18-84 years (mean age 45.7 years) treated in the Department and Clinic of Internal Diseases, Geriatrics and Allergology, Wroclaw Medical University. All patients with asthma who met the inclusion criteria participated in the study. We used medical record analysis and two questionnaires: the asthma quality of life questionnaire (AQLQ) and the asthma control test. Up-to-date sociodemographic data were collected from all participants, including sex, age, marital status, education, and sources of income.

Results: The sociodemographic variables that correlated positively with QoL in all domains of the AQLQ were professional activity and higher education level of respondents. Factors that negatively influenced the AQLQ domains were older age and lack of professional activity.

Conclusion: This study shows that age, physical work, and lack of professional activity decreased the QoL in this patient group. It was found that higher education contributes to better QoL scores.

Keywords: bronchial asthma, health related quality of life, sociodemographic factors

\section{Introduction}

The prevalence of bronchial asthma makes it a global public health issue. Estimates put the worldwide number of patients with asthma at $~ 300$ million and the number of deaths at $\sim 250,000$ a year. ${ }^{1}$ The concept of a holistic approach to patient care is based on the 1948 World Health Organization's definition of health. This involves providing the patients not only with comprehensive medical care but also with psychological and social support. ${ }^{2}$ The creators of the holistic approach to medicine mainly intended this approach to yield better treatment outcomes ${ }^{3}$ in chronic diseases, including asthma. However, the aims of holistic care should also include engaging the patient in the therapeutic process. ${ }^{4}$

A natural consequence of the holistic approach to medicine was the search for alternative measures of treatment effectiveness. As a result, in the 1990s, the concept of healthrelated quality of life (HRQoL) was introduced into clinical practice. ${ }^{5} \mathrm{HRQoL}$ is defined as the functional effects of the illness and treatment, as perceived by the patient. Thus, HRQoL comprises such components as the clinical condition and physical fitness of patients, as well as their psychological condition, social status, and somatic sensations. ${ }^{3,5}$
Correspondence: Bartosz Uchmanowicz Department of Clinical Nursing,

Division of Nursing in Internal Medicine Procedures, Wroclaw Medical University, Wroclaw, Poland Email izabella.uchmanowicz@umed.wroc.pl
Patient Preference and Adherence 2016:10 345-354

345

Dovepress

http://dx.doi.org/10.2147/PPA.S101898 (c) (1) (8) 2016 Uchmanowiz et al. This work is published and licensed by Dove Medical Press Limited. The full terms of this license are available at https://www.dovepress.com/terms.php cc) ${ }_{\mathrm{BY}} \mathrm{NC}$ and incorporate the Creative Commons Attribution - Non Commercial (unported, v3.0) License (http://creativecommons.org/licenses/by-nc/3.0/). By accessing the work you hereby accept the Terms. Non-commercial uses of the work are permitted without any further permission from Dove Medical Press Limited, provided the work is properly attributed. For permission for commercial use of this work, please see paragraphs 4.2 and 5 of our Terms (https://www.dovepress.com/terms.php). 
Such a comprehensive assessment of the quality of life (QoL) of patients has a range of applications. It can be used, eg, to screen for patients requiring additional support, to assess the impact of the illness and its treatment on the patient, and to analyze the quality of medical services rendered. ${ }^{6}$

The results of studies performed to date, using both generic and specific questionnaires, enabled the identification of numerous factors that may affect HRQoL in patients with asthma. These include the demographic, clinical, and personality characteristics of patient. The demographic factors related to the HRQoL of patients with asthma identified so far include sex, age, marital status, and education. ${ }^{7-9}$

The objective of this study was to analyze the sociodemographic factors affecting the QoL of patients with asthma.

\section{Patients}

The study comprised 100 patients ( 73 females and 27 males) aged 18-84 years (mean age was 45.7 years) treated in the Department and Clinic of Internal Diseases, Geriatrics and Allergology, Wroclaw Medical University, Wroclaw, Poland, and in the Allergy Clinic at the Kosmonautów Nonpublic Health Center in Wroclaw, Poland. All patients with asthma meeting the inclusion criteria participated in the study.

The inclusion criteria were as follows: 1) age 18 years or older, 2) a diagnosis of bronchial asthma, made at least 6 months before the study, according to the GINA 2012 criteria, and 3 ) informed consent expressed in writing.

The exclusion criteria were as follows: 1) lack of consent, 2) psychological disorders, and 3 ) other disorders preventing survey completion. The study protocol was approved by the Bioethics Committee of the Wroclaw Medical University (approval no 40/2014).

\section{Methods}

This study incorporated the following methods and instruments: medical record analysis and two questionnaires the asthma quality of life questionnaire (AQLQ) and the asthma control test. Up-to-date sociodemographic data were collected from all participants, including sex, age, marital status, education, and sources of income.

All participants received surveys and an information sheet stating that participation was voluntary and completely anonymous. The surveys were completed in the presence of the researcher. All patients received the following questionnaires.

\section{Adult AQLQ}

It is an instrument comprising 32 items for adult patients with asthma. It aims to identify the areas of functioning that are impaired by asthma in the adult patients. The survey can be administered by a researcher or self-administered by the patient. It measures four domains: activity limitation (eleven items), emotional function (five items), exposure to environmental stimuli (four items), and symptoms (12 items). The patients describe their experience with the condition in the previous 2 weeks, using a 7-point scale (1, severely impaired; 7, not impaired at all). The higher the score, the better the QoL. ${ }^{10}$

\section{Asthma control test}

It comprises five questions regarding the frequency of dyspnea, waking due to the symptoms, the need for rescue medication, and control of the condition as perceived by the patient. The maximum score is 25 and indicates perfect control. Scores at 24-20 points indicate well-controlled asthma but not fully controlled asthma, while scores $<20$ points indicate uncontrolled asthma. ${ }^{11-13}$

\section{Statistical methods}

Statistical analysis for quantitative characteristics (measurable variables) involved the calculation of basic statistics, ie, mean, standard deviation (SD), median, and extreme values - minimum and maximum. The normality of quantitative variable distribution was verified using the Shapiro-Wilk test at a significance level of $P=0.05$.

The significance of differences between quantitative variables with normal distributions in two groups (sex) was verified using Student's $t$-test for independent variables. If the distribution of a given variable significantly differed from normal or by variance, the nonparametric Mann-Whitney $U$-test was used.

Hypotheses on equality of means in more than two groups (eg, education and professional activity) were verified using either the analysis of variance (if variable distributions in all groups were not significantly different from normal) or the nonparametric Kruskal-Wallis test (for skewed distributions).

The strength of correlations between two quantitative variables was determined using Spearman's or Pearson's linear correlation coefficient $\left(r_{\mathrm{S}}\right.$ or $r$ ).

When correlation coefficients $r$ were significantly different from zero, regression analysis was performed, with linear correlation model parameter values determined for the two variables $(a$ and $b$ ) and correlation diagrams created, illustrating the dispersion of the variables against the mathematical model. The correlation of the quantitative variable (AQLQ) with several other variables (age and sex) was described using the multiple regression analysis. For qualitative variables 
(nominal or categorical), numbers (n) and percentages (\%) were calculated. The independence of qualitative variables was verified using the chi-squared test. For all statistical tests, $P<0.05$ was used as a statistical significance criterion. Calculations were made using the STATISTICA Version 10 software and the MS Excel spreadsheets.

\section{Results}

The study included 100 patients (73 females and 23 males) aged 18-84 years (mean age was 45.7 years) treated in the Department and Clinic of Internal Diseases, Geriatrics and Allergology, Wroclaw Medical University, Wroclaw, Poland. The sociodemographic and clinical characteristics of patients are shown in Tables 1 and 2 .

\section{Sociodemographic factors affecting the QoL as measured using AQLQ}

Factors affecting the QoL in the symptoms domain of the AQLQ

The only sociodemographic variable for which a significant correlation was found with the QoL in the symptoms domain of the AQLQ was the professional activity of respondents. Post hoc analysis showed disability pensioners to have a significantly lower QoL in this domain than professionally active respondents ( $P=0.006$; Table 3$)$. QoL in the symptoms domain was not significantly affected by the type of work ( $P=0.170)$, sex $(P=0.108)$, age $(R=-0.184, P=0.066)$, education $(R=0.180, P=0.077)$, residence $(R=0.120, P=0.232)$, and marital status $(P=0.695)$ of respondents (Table 3$)$.

Table I Sociodemographic characteristics of patients

\begin{tabular}{|c|c|c|c|c|}
\hline Sociodemographic data & Female (n) & Male (N) & $\%$ & $P$-value \\
\hline Sex & 73 & 27 & 100 & \\
\hline Age $(M \pm S D)$ & $44.07 \pm 15.40$ & & & \\
\hline \multicolumn{5}{|l|}{ Residence } \\
\hline Rural & 5 & 7 & 12 & 0.0170 \\
\hline Urban $<100,000$ residents & 11 & 2 & 13 & \\
\hline Urban $<500,000$ residents & 9 & 0 & 9 & \\
\hline Urban $>500,000$ residents & 48 & 18 & 66 & \\
\hline \multicolumn{5}{|l|}{ Education } \\
\hline Primary & 17 & 0 & 17 & 0.0039 \\
\hline Vocational & 14 & 9 & 23 & \\
\hline High school & 29 & 7 & 36 & \\
\hline College/university & 13 & 11 & 24 & \\
\hline \multicolumn{5}{|l|}{ Professional activity } \\
\hline Working & 22 & 6 & 28 & 0.3602 \\
\hline Unemployed & 1 & 0 & 1 & \\
\hline Disability pension claimant & 16 & 11 & 27 & \\
\hline Retired & 32 & 10 & 42 & \\
\hline Other status & 2 & 0 & 2 & \\
\hline \multicolumn{5}{|l|}{ Type of work } \\
\hline Blue collar & 27 & 9 & 38 & 0.3458 \\
\hline White collar & 38 & 16 & 57 & \\
\hline Others & 5 & 0 & 5 & \\
\hline \multicolumn{5}{|l|}{ Marital status } \\
\hline Married & 44 & 24 & 68 & 0.0155 \\
\hline Single & 4 & 1 & 5 & \\
\hline Widowed & 21 & 0 & 21 & \\
\hline Divorced & 4 & 2 & 6 & \\
\hline \multicolumn{5}{|l|}{ Smoking } \\
\hline No & 47 & 6 & 53 & 0.0002 \\
\hline Past & 21 & 20 & 41 & \\
\hline Yes & 5 & 1 & 6 & \\
\hline Cigarette smoking & 27 & 22 & & 0.4573 \\
\hline$M \pm S D$ & $22 \pm 3$ & $25 \pm 4$ & & \\
\hline Number of cigarettes smoked per day & 27 & 22 & & 0.3601 \\
\hline$M \pm S D$ & $17 \pm 10$ & $19 \pm 8$ & & \\
\hline Duration of the illness (years) & 73 & 27 & & 0.1444 \\
\hline$M \pm S D$ & $16.9 \pm 12.2$ & $14.1 \pm 13.4$ & & \\
\hline
\end{tabular}

Note: Bold $P$-value indicates statistical significance. Abbreviations: $M$, mean; SD, standard deviation. 
Table 2 Clinical characteristics of participants

\begin{tabular}{|c|c|c|c|c|}
\hline Clinical data & Female (n) & Male (N) & $\%$ & $P$-value \\
\hline \multicolumn{5}{|l|}{ Primary symptom } \\
\hline Daytime dyspnea episodes & 63 & 25 & 88 & 0.5214 \\
\hline Morning coughing & 7 & 2 & 9 & \\
\hline Night-time waking due to dyspnea & 3 & 0 & 3 & \\
\hline \multicolumn{5}{|l|}{ Acute asthma episodes } \\
\hline Daily (including nocturnal episodes) & 71 & 25 & 97 & 0.1191 \\
\hline Daily (during the day) & 1 & 0 & 1 & \\
\hline 3-4 per week & 0 & I & I & \\
\hline I per week & 0 & 0 & 0 & \\
\hline I per month & 0 & 0 & 0 & \\
\hline I every several months & 0 & 1 & 1 & \\
\hline \multicolumn{5}{|l|}{ Allergens $s^{\mathrm{a}}$} \\
\hline Animal dander & 23 & 7 & 30 & \\
\hline Pollen & 26 & 10 & 36 & \\
\hline Food & 37 & 9 & 46 & \\
\hline Dust & 14 & 1 & 15 & \\
\hline \multicolumn{5}{|l|}{ Allergy clinic visits } \\
\hline 2 per month & 8 & II & 19 & 0.0024 \\
\hline I per month & 24 & 3 & 27 & \\
\hline 6 per year & 17 & 2 & 19 & \\
\hline 3 per year & 8 & 2 & 10 & \\
\hline Fewer & 16 & 9 & 25 & \\
\hline \multicolumn{5}{|l|}{ Number of hospitalizations due to asthma } \\
\hline $1-2$ & 32 & 14 & 46 & 0.2648 \\
\hline $3-5$ & 8 & 6 & 14 & \\
\hline $6-10$ & 12 & 3 & 15 & \\
\hline$>10$ & 21 & 4 & 25 & \\
\hline \multicolumn{5}{|l|}{ Histamine test } \\
\hline Negative & 17 & 10 & 27 & 0.2622 \\
\hline Positive & 56 & 17 & 73 & \\
\hline \multicolumn{5}{|l|}{ Comorbidities $^{a}$} \\
\hline Diabetes mellitus & 12 & 2 & 14 & 0.4573 \\
\hline Arterial hypertension & 29 & 16 & 45 & \\
\hline Ischemic heart disease & 6 & 11 & 17 & \\
\hline Rheumatic disorders & 7 & 5 & 12 & \\
\hline Others & 19 & 6 & 25 & \\
\hline \multicolumn{5}{|l|}{ Asthma control test results } \\
\hline$M \pm S D$ & $11.8 \pm 4$ & $12.2 \pm 2.6$ & & 0.1465 \\
\hline $\mathrm{Me}$ & 11 & 12 & & \\
\hline Min-max & $4-22$ & $5-18$ & & \\
\hline \multicolumn{5}{|l|}{$\mathrm{FEV}_{1}(\mathrm{~L})$} \\
\hline$M \pm S D$ & $2.5 I \pm 0.57$ & $2.49 \pm 0.63$ & & 0.9076 \\
\hline $\mathrm{Me}$ & 2.70 & 2.60 & & \\
\hline Min-max & $0.65-3.50$ & $0.75-3.63$ & & \\
\hline \multicolumn{5}{|l|}{$\mathrm{FVC}(\mathrm{L})$} \\
\hline$M \pm S D$ & $3.19 \pm 0.84$ & $3.17 \pm 0.47$ & & 0.8919 \\
\hline $\mathrm{Me}$ & 3.21 & 3.20 & & \\
\hline Min-max & $1.01-6.63$ & I.72-3.70 & & \\
\hline \multicolumn{5}{|l|}{$\mathrm{FEV}_{1} / \mathrm{FVC}(-)$} \\
\hline$M \pm S D$ & $0.796 \pm 0.123$ & $0.777 \pm 0.172$ & & 0.5593 \\
\hline $\mathrm{Me}$ & 0.81 & 0.78 & & \\
\hline Min-max & $0.4 I-1.17$ & $0.39-1.32$ & & \\
\hline
\end{tabular}

Notes: Bold P-value indicates statistical significance; FEV,/FVC, FEV /FVC ratio. ${ }^{\text {TT }}$ The sum of percentages exceeds 100 due to possible multiple selections.

Abbreviations: $\mathrm{FEV}_{1}$, forced expiratory volume in I second; FVC, forced vital capacity; M, mean; Max, maximum; Me, median; Min, minimum.

Factors affecting the QoL in the activity limitation domain of the AQLQ

QoL in the activity limitation domain was shown to decrease significantly as the age of respondents increased $(R=-0.305$,
$P=0.002$; Table 4). It increased significantly with the education level of respondents ( $R=0.204, P=0.042$; Table 4). Another significant correlation was found between QoL in the activity limitation domain of the AQLQ and the professional 
Table 3 Statistical characteristics for QoL in the symptoms domain of the AQLQ in relation to sociodemographic factors

\begin{tabular}{|c|c|c|c|c|c|}
\hline Category & $\mathbf{n}$ & Me & Lower quartile & Upper quartile & $P$-value \\
\hline \multicolumn{6}{|l|}{ Sex } \\
\hline Female & 73 & 39 & 29 & 47 & \multirow[t]{2}{*}{0.108} \\
\hline Male & 27 & 31 & 22 & 47 & \\
\hline \multicolumn{6}{|l|}{ Age (Years) } \\
\hline I & 8 & 45 & 40 & 57 & \multirow[t]{8}{*}{0.066} \\
\hline 2 & 7 & 42 & 33 & 49 & \\
\hline 3 & 23 & 41 & 29 & 50 & \\
\hline 4 & 30 & 37 & 25 & 47 & \\
\hline 5 & 18 & 30 & 26 & 67 & \\
\hline 6 & 8 & 34 & 23 & 59 & \\
\hline 7 & 5 & 32 & 31 & 35 & \\
\hline 8 & 1 & 30 & 30 & 30 & \\
\hline \multicolumn{6}{|l|}{ Education } \\
\hline Primary & 17 & 39 & 30 & 47 & \multirow[t]{4}{*}{0.077} \\
\hline Vocational & 23 & 28 & 22 & 49 & \\
\hline High school & 36 & 34 & 28 & 42 & \\
\hline College/university & 24 & 45 & 38 & 66 & \\
\hline \multicolumn{6}{|l|}{ Professional activity } \\
\hline Working & 28 & 46 & 31 & 69 & \multirow[t]{5}{*}{0.005} \\
\hline Unemployed & 1 & 81 & 81 & 81 & \\
\hline Disability pension claimant & 27 & 26 & 18 & 42 & \\
\hline Retired & 42 & 39 & 30 & 47 & \\
\hline Other benefits & 2 & 39 & 39 & 39 & \\
\hline \multicolumn{6}{|l|}{ Type of work } \\
\hline Blue collar & 36 & 34 & 25 & 47 & \multirow[t]{3}{*}{0.170} \\
\hline White collar & 54 & 41 & 29 & 47 & \\
\hline Others & 10 & 30 & 26 & 33 & \\
\hline \multicolumn{6}{|l|}{ Residence } \\
\hline Rural & 12 & 31 & 28 & 37 & \multirow[t]{4}{*}{0.120} \\
\hline Urban $<100,000$ residents & 13 & 39 & 28 & 47 & \\
\hline Urban $<500,000$ residents & 9 & 41 & 26 & 67 & \\
\hline Urban $>500,000$ residents & 66 & 41 & 29 & 47 & \\
\hline \multicolumn{6}{|l|}{ Marital status } \\
\hline Married & 68 & 39 & 26 & 49 & \multirow[t]{4}{*}{0.695} \\
\hline Single & 5 & 44 & 44 & 47 & \\
\hline Widowed & 21 & 32 & 28 & 43 & \\
\hline Divorced & 6 & 41 & 32 & 42 & \\
\hline
\end{tabular}

Note: Bold $P$-values indicate statistical significance.

Abbreviations: AQLQ, asthma quality of life questionnaire; Me, median; QoL, quality of life.

Table 4 Statistical characteristics for QoL in the activity limitation domain of the AQLQ in relation to sociodemographic factors

\begin{tabular}{|c|c|c|c|c|c|}
\hline Category & $\mathbf{n}$ & Me & Lower quartile & Upper quartile & $P$-value \\
\hline \multicolumn{6}{|l|}{ Sex } \\
\hline Female & 73 & 37 & 27 & 47 & 0.972 \\
\hline Male & 27 & 36 & 30 & 55 & \\
\hline \multicolumn{6}{|l|}{ Age (years) } \\
\hline 1 & 8 & 39 & 35 & 60 & 0.002 \\
\hline 2 & 7 & 44 & 30 & 53 & \\
\hline 3 & 23 & 43 & 37 & 55 & \\
\hline 4 & 30 & 36 & 27 & 42 & \\
\hline 5 & 18 & 31 & 21 & 44 & \\
\hline 6 & 8 & 37 & 22 & 51 & \\
\hline 7 & 5 & 30 & 23 & 38 & \\
\hline 8 & 1 & 16 & 16 & 16 & \\
\hline \multicolumn{6}{|l|}{ Education } \\
\hline Primary & 17 & 34 & 22 & 47 & 0.042 \\
\hline Vocational & 23 & 33 & 20 & 50 & \\
\hline
\end{tabular}


Table 4 (Continued)

\begin{tabular}{|c|c|c|c|c|c|}
\hline Category & $\mathbf{n}$ & Me & Lower quartile & Upper quartile & $P$-value \\
\hline High school & 36 & 37 & 29 & 43 & \\
\hline College/university & 24 & 40 & 36 & 52 & \\
\hline \multicolumn{6}{|l|}{ Professional activity } \\
\hline Working & 28 & 47 & 38 & 53 & 0.001 \\
\hline Unemployed & 1 & 43 & 43 & 43 & \\
\hline Disability pension claimant & 27 & 30 & 13 & 41 & \\
\hline Retired & 42 & 36 & 27 & 43 & \\
\hline Other benefits & 2 & 43 & 43 & 43 & \\
\hline \multicolumn{6}{|l|}{ Type of work } \\
\hline Blue collar & 36 & 38 & 21 & 46 & 0.154 \\
\hline White collar & 54 & 37 & 33 & 53 & \\
\hline Others & 10 & 31 & 27 & 43 & \\
\hline \multicolumn{6}{|l|}{ Residence } \\
\hline Rural & 12 & 35 & 30 & 38 & 0.454 \\
\hline Urban $<100,000$ residents & 13 & 41 & 34 & 47 & \\
\hline Urban $<500,000$ residents & 9 & 34 & 26 & 63 & \\
\hline Urban $>500,000$ residents & 66 & 39 & 27 & 51 & \\
\hline \multicolumn{6}{|l|}{ Marital status } \\
\hline Married & 68 & 37 & 30 & 47 & 0.070 \\
\hline Single & 5 & 53 & 53 & 53 & \\
\hline Widowed & 21 & 30 & 22 & 41 & \\
\hline Divorced & 6 & 40 & 36 & 57 & \\
\hline
\end{tabular}

Note: Bold $P$-values indicate statistical significance.

Abbreviations: AQLQ, asthma quality of life questionnaire; Me, median; QoL, quality of life.

activity of respondents. Post hoc analysis showed disability pensioners to have a significantly lower QoL in this domain than professionally active respondents $(P<0.001$; Table 4$)$. QoL in the activity limitation domain was not significantly affected by the type of work $(P=0.154)$, sex $(P=0.972)$, residence $(R=0.076, P=0.454)$, and marital status $(P=0.070)$ of respondents (Table 4).

\section{Factors affecting the QoL in the emotional function} domain of the AQLQ

QoL in the emotional function domain was shown to decrease significantly as the age of respondents increased $(R=-0.197$, $P=0.049$; Table 5). Another significant correlation was found between QoL in this domain of the AQLQ and the professional activity of respondents. Post hoc analysis showed

Table 5 Statistical characteristics for QoL in the emotional function domain of the AQLQ in relation to sociodemographic factors

\begin{tabular}{|c|c|c|c|c|c|}
\hline Category & $\mathbf{n}$ & Me & Lower quartile & Upper quartile & $P$-value \\
\hline \multicolumn{6}{|l|}{ Sex } \\
\hline Female & 73 & 20 & 15 & 25 & 0.473 \\
\hline Male & 27 & 18 & 13 & 28 & \\
\hline \multicolumn{6}{|l|}{ Age (Years) } \\
\hline I & 8 & 20 & 20 & 25 & 0.049 \\
\hline 2 & 7 & 20 & 15 & 24 & \\
\hline 3 & 23 & 21 & 17 & 29 & \\
\hline 4 & 30 & 20 & 14 & 22 & \\
\hline 5 & 18 & 15 & 11 & 26 & \\
\hline 6 & 8 & 17 & 14 & 25 & \\
\hline 7 & 5 & 17 & 15 & 18 & \\
\hline 8 & I & 22 & 22 & 22 & \\
\hline \multicolumn{6}{|l|}{ Education } \\
\hline Primary & 17 & 20 & 16 & 22 & 0.643 \\
\hline Vocational & 23 & 18 & 12 & 29 & \\
\hline High school & 36 & 20 & 13 & 22 & \\
\hline College/university & 24 & 20 & 17 & 29 & \\
\hline \multicolumn{6}{|l|}{ Professional activity } \\
\hline Working & 28 & 24 & 16 & 34 & 0.013 \\
\hline
\end{tabular}


Table 5 (Continued)

\begin{tabular}{lllll}
\hline Category & $\mathbf{n}$ & Me & Lower quartile & Upper quartile \\
\hline Unemployed & 1 & 35 & 35 & 35 \\
Disability pension claimant & 27 & 18 & 12 & 20 \\
Retired & 42 & 19 & 16 & 22 \\
Other benefits & 2 & 20 & 20 & 20 \\
Type of work & & & & 29 \\
Blue collar & 36 & 20 & 13 & 23 \\
White collar & 54 & 20 & 15 & 24 \\
Others & 10 & 20 & 15 & 26 \\
Residence & 12 & 18 & 13 & 24 \\
Rural & 13 & 20 & 20 & 22 \\
Urban $<100,000$ residents & 9 & 20 & 12 & 26 \\
Urban $<500,000$ residents & 66 & 19 & 14 & \\
Urban $>500,000$ residents & & & & 27 \\
Marital status & 68 & 20 & 15 & 33 \\
Married & 5 & 24 & 21 & 22 \\
Single & 21 & 19 & 12 & 19 \\
Widowed & 6 & 18 & 14 & 0.885 \\
Divorced & & & & \\
\hline
\end{tabular}

Abbreviations: AQLQ, asthma quality of life questionnaire; Me, median; QoL, quality of life.

disability pensioners to have a significantly lower QoL in the emotional function domain than professionally active respondents $(P<0.021$; Table 5$)$. QoL in the emotional function domain was not significantly affected by the type of work $(P=0.885)$, sex $(P=0.473)$, education $(R=0.047$, $P=0.643)$, residence $(R=-0.016, P=0.873)$, and marital status $(P=0.136)$ of respondents (Table 5$)$.

\section{Factors affecting the QoL in the environmental} stimuli domain of the AQLQ

QoL in the environmental stimuli domain was shown to decrease significantly as the age of respondents increased ( $R=-0.317, P=0.001$; Table 6). Another significant correlation was found between QoL in this domain of the AQLQ and the type of work of respondents. Those in blue-collar jobs had a significantly lower QoL in the environmental stimuli domain than white-collar workers $(P=0.034$; Table 6). QoL in this domain was not significantly affected by the sex $(P=0.724)$, education $(R=0.131, P=0.195)$, residence $(R=-0.131$, $P=0.193)$, professional activity $(P=0.202)$, and marital status $(P=0.460)$ of respondents (Table 6$)$.

\section{Discussion}

Patients diagnosed with asthma experience a number of problems with regard to everyday activities and functions, which adversely affects their HRQoL. This study shows that

Table 6 Statistical characteristics for QoL in the environmental stimuli domain of the AQLQ in relation to sociodemographic factors

\begin{tabular}{|c|c|c|c|c|c|}
\hline Category & $\mathbf{n}$ & Me & Lower quartile & Upper quartile & $P$-value \\
\hline \multicolumn{6}{|l|}{ Sex } \\
\hline Female & 73 & 15 & 10 & 17 & 0.724 \\
\hline Male & 27 & 16 & 7 & 20 & \\
\hline \multicolumn{6}{|l|}{ Age (years) } \\
\hline 1 & 8 & 16 & 14 & 21 & 0.001 \\
\hline 2 & 7 & 16 & 11 & 21 & \\
\hline 3 & 23 & 17 & 12 & 20 & \\
\hline 4 & 30 & 15 & 10 & 17 & \\
\hline 5 & 18 & 11 & 7 & 15 & \\
\hline 6 & 8 & 13 & 7 & 21 & \\
\hline 7 & 5 & 14 & 10 & 15 & \\
\hline 8 & 1 & 7 & 7 & 7 & \\
\hline \multicolumn{6}{|l|}{ Education } \\
\hline Primary & 17 & 15 & 10 & 18 & 0.195 \\
\hline Vocational & 23 & 11 & 6 & 16 & \\
\hline
\end{tabular}


Table 6 (Continued)

\begin{tabular}{|c|c|c|c|c|c|}
\hline Category & $\mathbf{n}$ & Me & Lower quartile & Upper quartile & $P$-value \\
\hline High school & 36 & 15 & 10 & 18 & \\
\hline College/university & 24 & 16 & 12 & 19 & \\
\hline \multicolumn{6}{|l|}{ Professional activity } \\
\hline Working & 28 & 15 & 10 & 17 & 0.202 \\
\hline Unemployed & 1 & 25 & 25 & 25 & \\
\hline Disability pension claimant & 27 & 14 & 5 & 20 & \\
\hline Retired & 42 & 15 & 12 & 18 & \\
\hline Other benefits & 2 & 11 & 11 & 11 & \\
\hline \multicolumn{6}{|l|}{ Type of work } \\
\hline Blue collar & 36 & 12 & 7 & 16 & 0.033 \\
\hline White collar & 54 & 16 & 11 & 19 & \\
\hline Others & 10 & 13 & 6 & 16 & \\
\hline \multicolumn{6}{|l|}{ Residence } \\
\hline Rural & 12 & 15 & 10 & 16 & 0.193 \\
\hline Urban $<100,000$ residents & 13 & 17 & 16 & 20 & \\
\hline Urban $<500,000$ residents & 9 & 16 & 10 & 24 & \\
\hline Urban $>500,000$ residents & 66 & 14 & 9 & 17 & \\
\hline \multicolumn{6}{|l|}{ Marital status } \\
\hline Married & 68 & 16 & 11 & 18 & 0.460 \\
\hline Single & 5 & 15 & 11 & 15 & \\
\hline Widowed & 21 & 12 & 7 & 20 & \\
\hline Divorced & 6 & 12 & 10 & 21 & \\
\hline
\end{tabular}

Note: Bold $P$-value indicates statistical significance.

Abbreviations: AQLQ, asthma quality of life questionnaire; Me, median; QoL, quality of life.

the sociodemographic determinants of subjective HRQoL are understood as the functional effects of the illness and its treatment, as perceived by the patients, and it reflects the four fundamental areas of functioning: physical health and fitness, psychological condition, somatic sensations, and socioeconomic standing of patients. What is clearly noticeable is that HRQoL is a multidimensional concept reflecting numerous aspects of human functioning. It is, however, highly subjective and dependent on the psychological state, personality, preferences, and values of an individual. The results of studies performed to date, using both generic and specific questionnaires, enabled the identification of numerous factors that may affect the HRQoL in patients with asthma. This study identified a number of determinants affecting the QoL of patients with asthma. The discussion of particular AQLQ domains focused on sociodemographic variables (age, sex, education, professional activity, residence, and marital status) that may affect the HRQoL of patients with asthma.

In the symptoms domain of the AQLQ, the one variable that adversely affected the HRQoL was the lack of professional activity. Disability pensioners had a significantly lower QoL in this domain than professionally active respondents. Similar results were obtained by Szynkiewicz et $\mathrm{a}^{13}$ in their study on the impact of sociodemographic factors on the HRQoL of patients with asthma. They confirmed that the professional status of respondents is a factor in their HRQoL.
Analysis of factors influencing the activity limitation subscale of the AQLQ showed that HRQoL decreased as the age of respondents increased - as in the case of the symptoms subscale. Studies by other authors corroborate the present results. ${ }^{14-16}$ In the activity limitation subscale, older age was also a determinant of lower QoL scores. Most likely, the clinical presentation of asthma is also affected by aging processes in the respiratory system. Years of asthma may contribute to the development of irreversible obstructive disorders, making the condition similar to chronic obstructive pulmonary disease. Persistent obstructive disorders are commonly described in elderly patients with asthma. Lindner et $\mathrm{al}^{17}$ and Ouztürk et $\mathrm{al}^{18}$ reported that elderly patients with asthma had lower QoL, though proper treatment could improve the result in this patient group. This is corroborated by Hazell et al, ${ }^{19}$ reporting decreases in the QoL with increase in the age of patients. Another correlation was found between QoL in the activity limitation subscale and professional activity. Disability pensioners had a significantly lower QoL in this domain. As stated earlier, this is corroborated by Szynkiewicz et al. ${ }^{13}$ Studies performed by Laforest et $\mathrm{al}^{20}$ and Ferreira et $\mathrm{al}^{21}$ also reported that professional activity leads to a higher assessment of HRQoL among patients with bronchial asthma. However, in the study conducted by Hans-Wytrychowska et al, ${ }^{22}$ that correlation was not confirmed. 
Analysis of factors influencing the emotional function subscale of the AQLQ showed that QoL decreased as the age of respondents increased - as in the case of the symptoms and "activity limitation" subscales. With regard to professional activity, disability pensioners were characterized by a significantly lower QoL in this domain, which had been discussed and confirmed by other authors. ${ }^{23}$ The analysis of factors influencing the environmental stimuli subscale of the AQLQ showed that QoL decreased as the age of respondents increased - as in the case of the remaining subscales. Furthermore, a significantly decreased QoL in the environmental stimuli subscale was enjoyed by blue-collar workers than by white-collar workers. It can be concluded that patients with a higher education level have more knowledge and awareness about their illness, which results in better compliance with treatment. Chen et $\mathrm{al}^{24}$ have also proved that a low level of education results in lower QoL in patients with bronchial asthma. Similar findings were confirmed by the research done by Ferreira et al, ${ }^{21}$ indicating that QoL is better in patients with higher education and higher income. In addition, Blozik et $\mathrm{al}^{25}$ have proved that lower $\mathrm{QoL}$ was associated with lower education.

A similar view was shared by Uchmanowicz et al, ${ }^{26}$ indicating that HRQoL is better in patients with higher education level. It can be concluded that patients with a higher education level have more knowledge and awareness about their illness, which results in better compliance with treatment.

\section{Implications of the study}

This study demonstrates that proper therapeutic interventions and patient education are the key to increase the QoL of patients. These factors enable the patients to adapt to their illness and may promote better compliance with treatment, contributing to better objective health.

\section{Conclusion}

Chronic disease lowers the QoL. Especially, asthma is a condition that significantly affects the HRQoL in various ways. The present study showed that age, physical work, and lack of professional activity decreased the QoL in this patient group. It was found that higher education contributes to better QoL scores.

\section{Disclosure}

The authors report no conflicts of interest in this work.

\section{References}

1. Masoli M, Fabian D, Holt S, Beasley R. Global initiative for asthma program: the global burden of asthma: executive summary of the GINA Dissemination Committee Report. Allergy. 2004;59:469-478.
2. The World Health Organization Quality of Life Assessment (WHOQOL): position paper from the World Health Organization. Soc Sci Med. 1995;41:1403-1409.

3. Schipper H. Quality of life. Principle of the clinical paradigm. J Psychosocial Oncol. 1990;8:171-185.

4. Ostrzyżek A. Jakość życia w chorobach przewlekłych [Quality of life in chronic diseases]. Probl Hig Epidemiol. 2008;89:467-470.

5. Dalkey NC, Rourke DL. The Delphi Procedure and Rating Quality of Life Factors. University of California, LA; 1972.

6. Higginson I, Carr AJ. Measuring quality of life: using quality of life measures in the clinical setting. Br Med J. 2001;322:1297-1300.

7. Zashikhina A, Hagglof B. Health-related quality of life in adolescents with chronic physical illness in northern Russia: a cross-sectional study. Health Qual Life Outcomes. 2014;12:12.

8. Wang KY, Wu CP, Tang YY, Yang ML. Health-related quality of life in Taiwanese patients with bronchial asthma. J Formos Med Assoc. 2004;103:205-211.

9. Koskela J, Kupiainen H, Kilpelainen M, et al. Longitudinal HRQoL shows divergent trends and identifies constant decliners in asthma and COPD. Respir Med. 2014;108:463-471.

10. Juniper EF, Guyatt GH, Ferrie PJ, Griffith LE. Measuring quality of life in asthma. Am Rev Respir Dis. 1993;147:832-838.

11. Nathan RA, Sorkness CA, Kosinski M, et al. Development of the asthma control test: a survey for assessing asthma control. J Allergy Clin Immunol. 2004;113(1):59-65.

12. Testa MA. Assessment of quality of life outcomes. $N$ Engl J Med. 1996;334:835.

13. Szynkiewicz E, Filanowicz M, Graczyk M, et al. Analysis of the impact of selected socio-demographic factors on quality of life of asthma patients. Postep Derm Alergol. 2013;XXX(4):218-225.

14. Ponte EV, Petroni J, Ramos DCB, et al. Perception of asthma control in asthma patients. J Bras Pneumol. 2007;33:635-640.

15. Uchmanowicz I, Jankowska B, Panaszek B, Fal AM. The influence of socio-demographic factors on quality of life of patients with asthma. Polish Alergol Info. 2010;5:57-65.

16. Uchmanowicz B, Panaszek B. Wybrane parametry oceny jakości życia zależnej od zdrowia (HRQoL) chorych na astmę oskrzelową [Selected parameters of quality of life on the health related quality of life (HRQoL) in patients with bronchial asthma] Contemp Nursing Public Health/ Wspótcz Pielegg Ochr Zdr. 2013;2(1):2-6. [Polish].

17. Lindner K, Panaszek B, Machaj Z. Astma u osób starszych [Asthma in elderly patients]. Pol Arch Med Wewn. 2007;117(8):350-354.

18. Ouztürk Ö, Ekici A, Kara M, et al. Psychological status and quality of life in elderly patients with asthma. Psychosomatics. 2005;46: $41-46$.

19. Hazell M, Frank T, Frank P. Health related quality of life in individuals with asthma related symptoms. Respir Med. 2003;97(11):1211-1218.

20. Laforest L, Pacheco Y, Bartsch P, et al. Correlates of quality of life in patients with asthma. Ann Allerg Asthma Im. 2005;94:473-479.

21. Ferreira LN, Brito U, Ferreira PL. Quality of life in asthma patients. Rev Pol Pneumol. 2010;16:23-55.

22. Hans-Wytrychowska A, Kurpas D, Sapilak BJ. The impact of socioeconomic status on the level of asthma control and the assessment of health-related quality of life (HRQoL) - own research. Fam Med Prim Care Rev. 2010;12:202-206. [Polish].

23. Chełmińska M, Werachowska L, Niedoszytko M, et al. Quality of life in patients with well- and poorly controlled asthma. Pneumonol Alergol Pol. 2007;75:70-75. [Polish].

24. Chen H, Gould M, Blanc P, et al. Asthma control, severity, and quality of life: quantifying the effect of uncontrolled disease. J Allergy Clin Immunol. 2007;120:396-402.

25. Blozik E, Demmer I, Kochen MW, et al. Health-related quality of life in asthma patients from general practice. Dtsch Med Wochenschr. 2009;134:873-878.

26. Uchmanowicz I, Fal AM, Jankowska-Polasińska B. Does sex affect the results of quality of life in patients with asthma? Alergol Info. 2011;6:46-51. [Polish]. 


\section{Publish your work in this journal}

Patient Preference and Adherence is an international, peer-reviewed, open access journal that focuses on the growing importance of patient preference and adherence throughout the therapeutic continuum. Patient satisfaction, acceptability, quality of life, compliance, persistence and their role in developing new therapeutic modalities and compounds to optimize

clinical outcomes for existing disease states are major areas of interest for the journal. This journal has been accepted for indexing on PubMed Central. The manuscript management system is completely online and includes a very quick and fair peer-review system, which is all easy to use. Visit http://www. dovepress.com/testimonials.php to read real quotes from published authors.

Submit your manuscript here: http://www.dovepress.com/patient-preference-and-adherence-journal 